\title{
Hereditary leiomyomatosis and renal cell cancer syndrome - case report and review of the literature
}

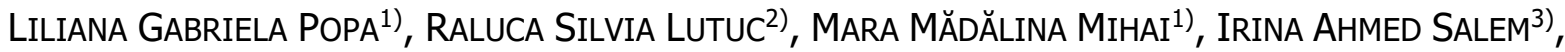

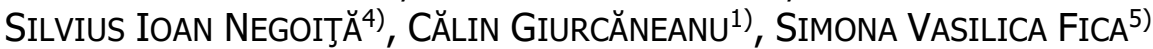 \\ 1) Department of Dermatology, Elias Emergency University Hospital, Bucharest, Romania; \\ Department of Dermatology, Carol Davila University of Medicine and Pharmacy, Bucharest, Romania \\ 2) Department of Dermatology, Elias Emergency University Hospital, Bucharest, Romania \\ 3) Department of Pathology, Elias Emergency University Hospital, Bucharest, Romania \\ 4) Department of Anesthesiology and Intensive Care, Elias Emergency University Hospital, Bucharest, Romania; \\ Department of Anesthesiology and Intensive Care, Carol Davila University of Medicine and Pharmacy, Bucharest, \\ Romania \\ ${ }^{5)}$ Department of Endocrinology, Elias Emergency University Hospital, Bucharest, Romania; \\ Department of Endocrinology, Carol Davila University of Medicine and Pharmacy, Bucharest, Romania
}

\begin{abstract}
Hereditary leiomyomatosis and renal cell cancer syndrome (HLRCC) is an exceptionally rare autosomal dominant condition caused by a germline heterozygous mutation of the fumarate hydratase gene. It manifests as multiple piloleiomyomas, associated with numerous, earlyonset uterine leiomyomas in female patients, as well as a highly increased risk of renal cell carcinoma (RCC), most often type 2 papillary RCC. HLRCC has been described in association with adrenal cortical hyperplasia, pheochromocytoma, adrenal cortical carcinoma, and other solid tumors, but the exact relationship between these disorders has not yet been clarified. We present a case of HLRCC associated with bilateral adrenal cortical hyperplasia and discuss the pathogenesis, clinical and paraclinical features of HLRCC, as well as the adequate management of these patients.
\end{abstract}

Keywords: hereditary leiomyomatosis, fumarate hydratase, leiomyoma, renal cell cancer.

\section{Introduction}

Described by Kloepfer et al., in 1958 [1] and later by Reed et al., in 1973 [2], hereditary leiomyomatosis and renal cell cancer syndrome (HLRCC), also known as multiple cutaneous and uterine leiomyomatosis (MCUL) is an exceptionally rare hereditary condition. Up to this moment, it has only been reported in approximately 200 families [3]. The disorder is usually inherited in an autosomal dominant fashion with variable penetrance but can also develop de novo [4]. The genetic defect is represented by a germline heterozygous mutation of the MCUL 1 locus of the fumarate hydratase $(F H)$ gene, located on chromosome 1q42.3-q43 [5]. The gene encodes for the FH enzyme, which converts fumarate to malate in the tricarboxylic acid (Krebs) cycle [6].

LRCC manifests as multiple piloleiomyomas, associated with numerous, early-onset uterine leiomyomas in female patients, as well as a highly increased risk of renal cell carcinoma (RCC), most often type 2 papillary RCC [7].

Germline mutations of the $F H$ gene have also been detected in patients diagnosed with malignant pheochromocytomas and paragangliomas [8].

\section{Aim}

We present a case of HLRCC associated with bilateral adrenal cortical hyperplasia and discuss the pathogenesis, clinical and paraclinical features of HLRCC, as well as the adequate management of these patients.

\section{a Case presentation}

A 62-year-old female patient was referred to the Department of Dermatology, Elias Emergency University Hospital, Bucharest, Romania, in January 2019 for the presence of multiple skin colored, smooth nodular lesions of different sizes, ranging from $0.3 \mathrm{~cm}$ to $2 \mathrm{~cm}$, located on the face, trunk and limbs (Figures 1 and 2).
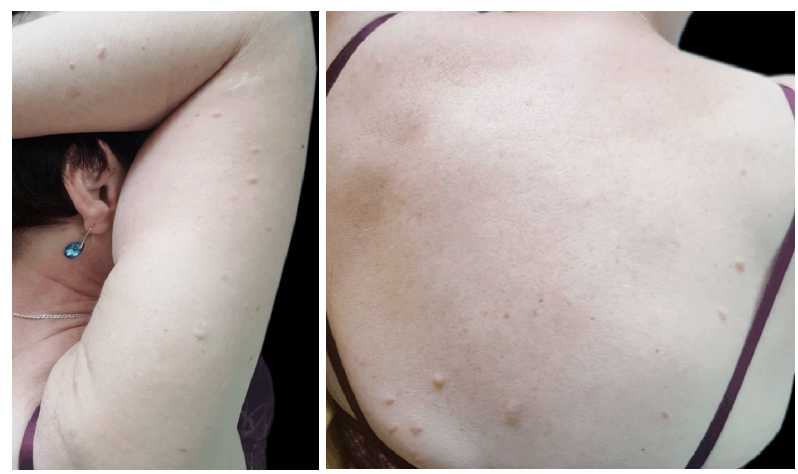

Figure 1-Multiple skin Figure 2-Multiple piloleiomyomas colored, smooth papules located on the trunk.

and nodules, $0.3-2 \mathrm{~cm}$

in diameter, located on the upper limb.

This is an open-access article distributed under the terms of a Creative Commons Attribution-NonCommercial-ShareAlike 4.0 International Public License, which permits unrestricted use, adaptation, distribution and reproduction in any medium, non-commercially, provided the new creations are licensed under identical terms as the original work and the original work is properly cited. 
The skin lesions first appeared several years previously on the arms and gradually increased in number and size. The patient complained of pain in some of the lesions, both spontaneous and precipitated by touch and exposure to cold. The rest of the physical examination did not reveal pathological changes.

Her family medical history was relevant as her two sisters, her daughter and her niece had developed multiple symptomatic uterine leiomyomas in their third decade of life, necessitating repeated myomectomies and all presented similar skin lesions.

The patient had a personal history of uterine leiomyomatosis for which she had undergone multiple myomectomies before the age of 30 and eventually a total hysterectomy. She had also suffered an ureteroscopic removal of a polypoid benign tumor. She had been diagnosed with arterial hypertension, ischemic heart disease, bronchiectasis, and chronic gastritis for which she was under chronic treatment with antihypertensive, antiaggregant, and gastric antisecretory drugs. A thoracic and abdominal computed tomography (CT) scan performed 10 years previously showed, apart from bronchiectasis, a $2.4 / 1.4 \mathrm{~cm}$ hypodense nodule in the right adrenal gland and a micronodular left adrenal hyperplasia. Repeated subsequent blood tests revealed high levels of chromogranin A (a maximum level of $560 \mu \mathrm{g} / \mathrm{L}$; normal levels 27-94 $\mu \mathrm{g} / \mathrm{L}$ ) and gastrin (a maximum level of $322 \mathrm{pg} / \mathrm{mL}$; normal level $<100 \mathrm{pg} / \mathrm{mL}$ ). The seric levels of aldosterone, renin, basal and overnight cortisol, corticotropin, catecholamines, 5-hydroxyindoleacetic acid, serotonin were all within normal limits. A neuroendocrine tumor was suspected. Laparoscopic right adrenalectomy was performed and the histopathological (HP) diagnosis was that of microand macronodular hyperplasia of the zona fasciculata and zona reticularis. Extensive investigations were carried out, but a neuroendocrine tumor was not detected. A $2 \mathrm{~cm}$ cyst located in the right renal cortex was identified on abdominal ultrasound (US). Its cystic nature was confirmed by abdominal and pelvic CT scans and magnetic resonance imaging (MRI).

The patient was admitted to our Clinic for further investigations. Laboratory tests results were within normal limits except for the elevated seric levels of chromogranin $\mathrm{A}$ and gastrin. Gastritis was diagnosed on endoscopic examination. Helicobacter pylori infection was also found and treated. After completion of treatment for $H$. pylori infection, the gastrin level normalized $(54 \mathrm{pg} / \mathrm{mL})$. As the increased chromogranin A level could be explained by the chronic treatment with proton-pump inhibitors that our patient had followed, the administration of these drugs was ceased for approximately two weeks. After this interval, the level of chromogranin A also returned to normal $(31 \mu \mathrm{g} / \mathrm{L})$, confirming the clinical suspicion. The thoracic, abdominal and pelvic CT scan revealed the presence of bronchiectasis, compensatory left adrenal hyperplasia, and the $2 \mathrm{~cm}$ cyst of the right renal cortex.

A skin biopsy was performed and the HP examination showed the presence of a dermal tumor composed of smooth muscle fibers with yellow cytoplasm, minimal nuclear and cytoplasmic pleomorphism, perinuclear cytoplasmic vacuolization on van Gieson staining, peri- and intratumoral minimal inflammatory lymphocytic infiltrate, intertwined with collagen bundles. The overlying epidermis was atrophic, with flattened rete ridges and hyperpigmentation of the basal layer (Figures 3, A and B; Figure 4, A and B). The HP diagnosis was that of leiomyoma and it was confirmed by immunohistochemical staining that showed diffuse positivity for actin and vimentin, faint focal positivity for S100 and factor XIIIa, positivity for cluster of differentiation 34 (CD34) limited to endothelial cells and for Leu 7 limited to nerve fibers, and $<1 \%$ positivity for Ki67 (Figure 5, A-D).

Based on the clinical picture, the HP results and the personal and family medical history, the clinical diagnosis of HLRCC was established.

\section{ㅁ Discussions}

Heterozygous $\mathrm{FH}$ mutations represent the genetic basis of HLRCC, having been documented in 76-100\% of families with HLRCC [9]. Contrastingly, homozygous or compound heterozygous germline $\mathrm{FH}$ mutations inherited in an autosomal recessive fashion are responsible for neonatal progressive neurological impairment, which is usually lethal in the first few months of life [10].

The most common pathogenic variants are missense. Nonsense, frameshift, splice-site mutations, as well as partial and whole-gene deletions have also been detected in patients with HLRCC $[11,12]$. However, a certain genotype does not predict the phenotype [11].
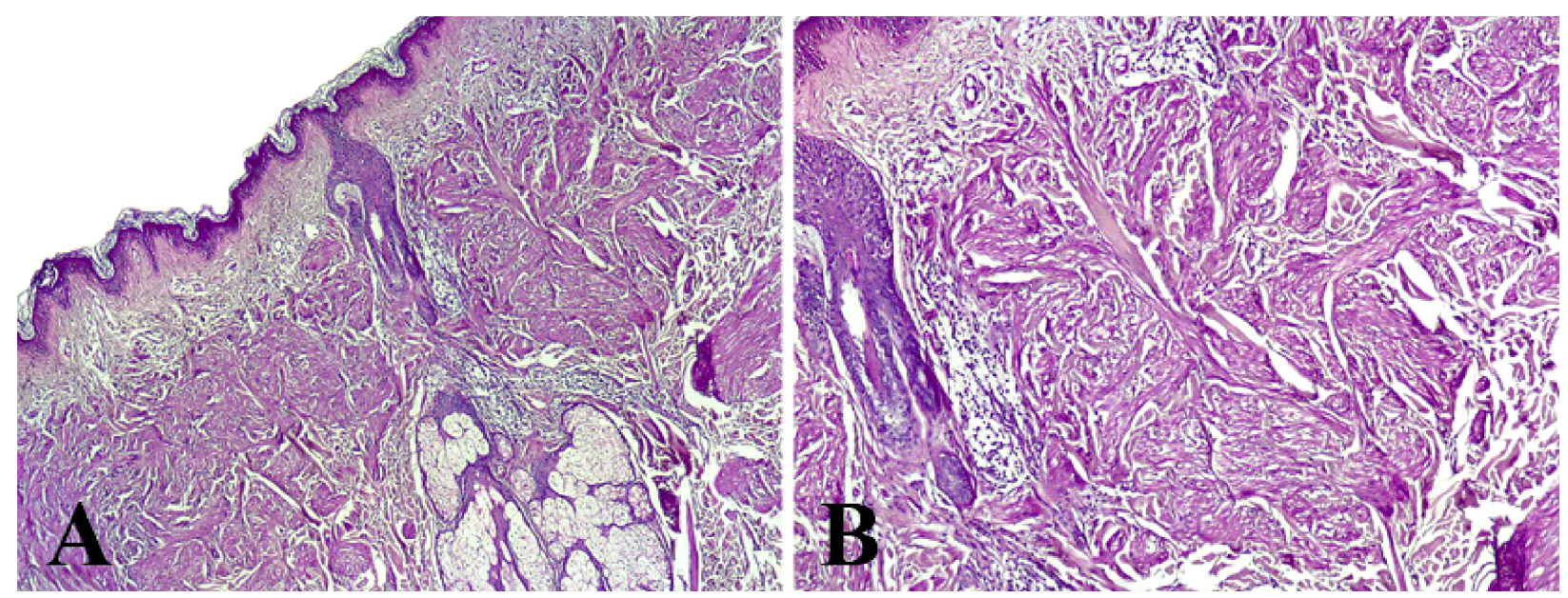

Figure 3 - (A and B) Dermal tumor composed of smooth muscle fibers, peri- and intratumoral minimal inflammatory lymphocytic infiltrate, intertwined with collagen bundles. The overlying epidermis is atrophic, with flattened rete ridges and hyperpigmentation of the basal layer. Hematoxylin-Eosin $(\mathrm{HE})$ staining: $(A) \times 50 ;(B) \times 100$. 


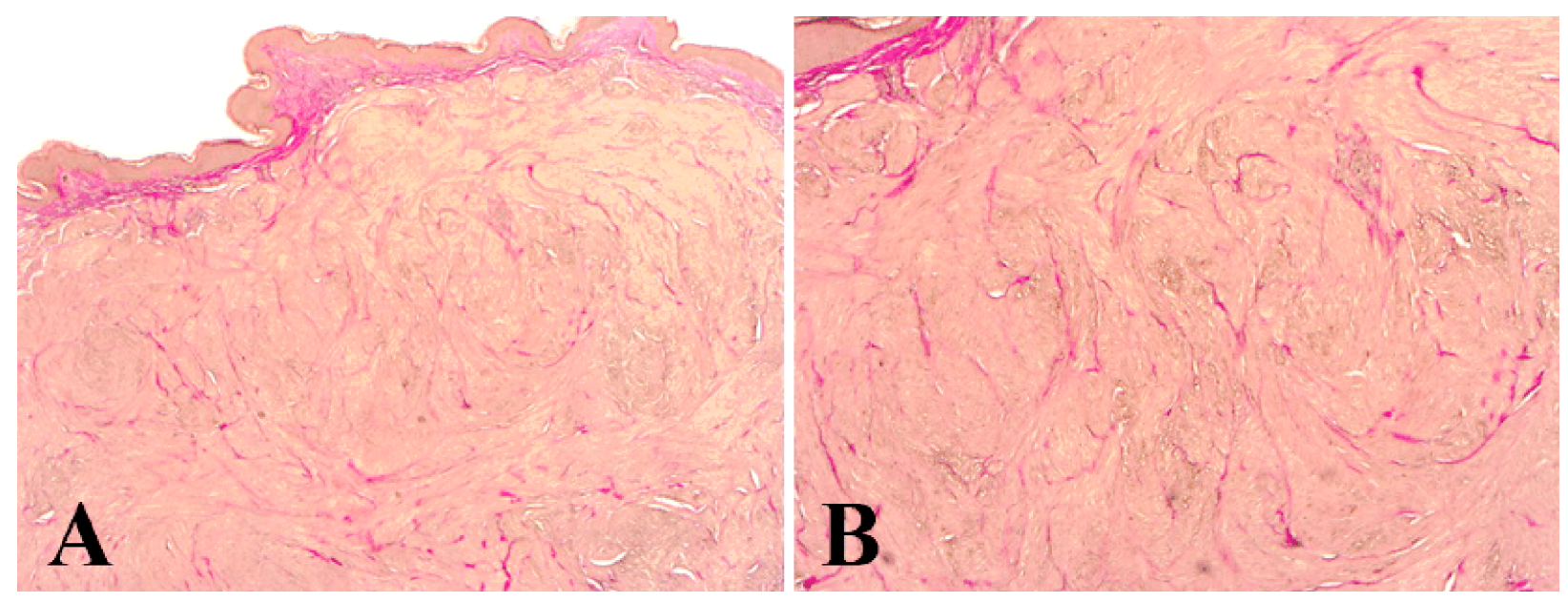

Figure 4 - (A and B) Dermal tumor composed of smooth muscle fibers, with yellow cytoplasm, minimal nuclear and cytoplasmic pleomorphism, perinuclear cytoplasmic vacuolization, peri- and intratumoral minimal inflammatory lymphocytic infiltrate, interlaced with collagen fibers. Van Gieson staining: $(A) \times 50 ;(B) \times 100$.
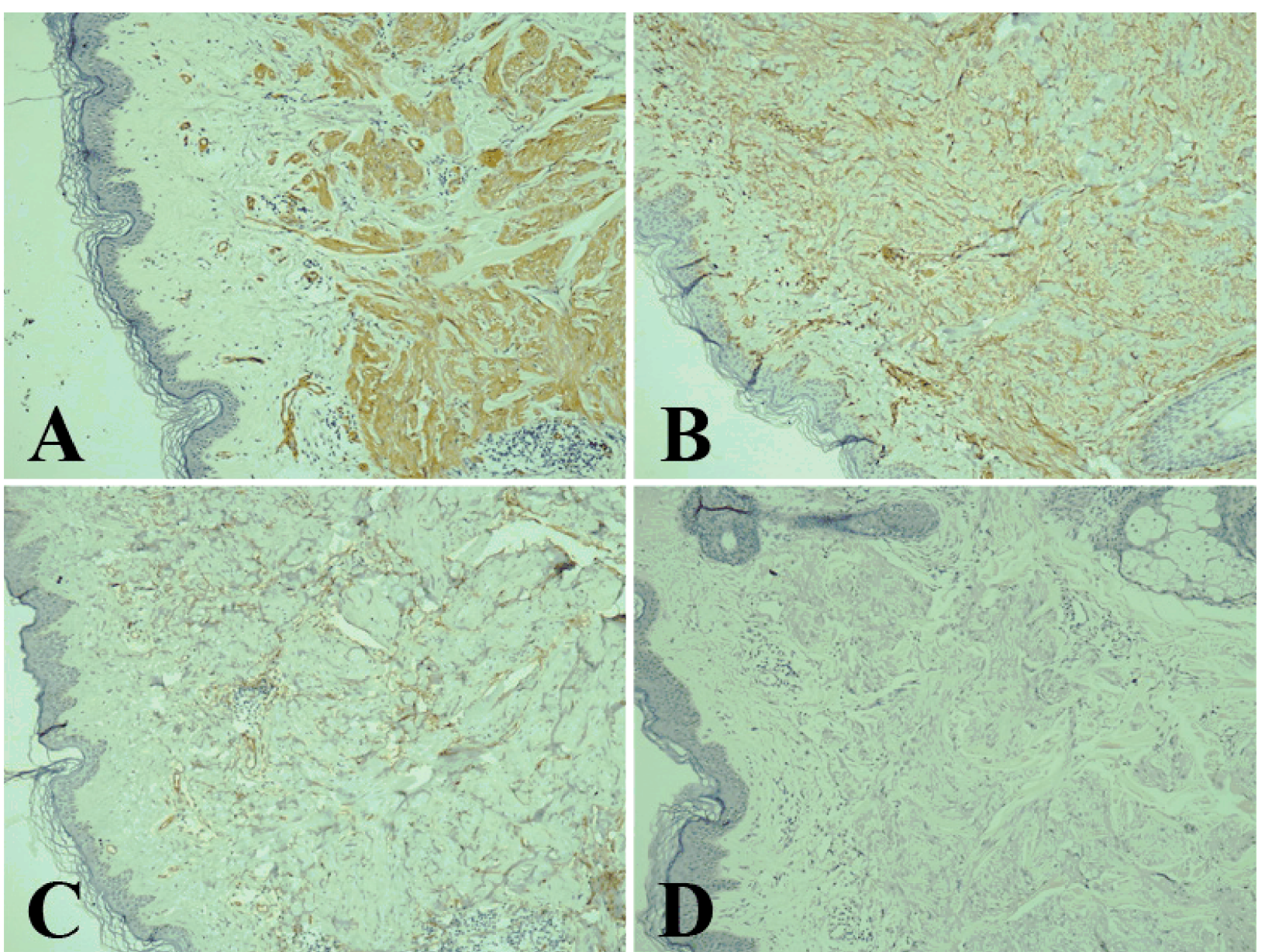

Figure 5 - (A-D) Immunohistochemical staining showing diffuse positivity for actin $(A, \times 50)$ and vimentin $(B, \times 50)$, positivity for CD34 limited to endothelial cells $(C, \times 100)$ and for Leu 7 limited to nerve fibers $(D, \times 100)$. CD34: Cluster of differentiation 34.

FH mutations induce carcinogenesis mainly through the activation of the hypoxia pathway. The decrease in the enzyme's function leads to the accumulation of fumarate, which competitively inhibits the degradation of hypoxiainducible factor (HIF)-1 $\alpha$ by prolyl hydroxylases. HIF-1 is a transcription factor that controls the response to changes in cellular oxygenation [13]. Its enzymatic lysis is reduced in case of low oxygen tension, thus promoting cell survival and growth [13]. In HLRCC, despite normal cellular oxygenation, HIF $1-\alpha$ level is increased, generating a state of pseudo-hypoxia that explains tumor growth [14, 15]. Additional mechanisms involved in tumorigenesis include the production of reactive oxygen species that contribute to the stabilization of HIF-1 $\alpha$ and the potential of intracellular fumarate to mediate epigenetic effects [16].

Multiple studies have also reported an association between $\mathrm{FH}$ gene mutations and the development of sporadic tumors, therefore it has been hypothesized that it 
functions as a tumor suppressor gene [5, 17]. However, this is still a controversial issue as subsequent research did not confirm the role of $\mathrm{FH}$ gene defects in sporadic tumorigenesis $[18,19]$.

The clinical picture of HLRCC is highly characteristic, but the severity of the disease considerably varies between families and within the same family [11, 20]. Most patients present solitary or multiple cutaneous leiomyomas. These are benign smooth muscle tumors arising most often from the arrector pili muscle (piloleiomyomas) and less frequently originating in the genital and areolar smooth muscles or the vascular smooth muscles (angioleiomyomas) [21]. They generally appear during young adulthood, the mean age of onset being 25 years [22]. On physical examination, multiple firm, smooth skin-colored or pink papules or nodules, ranging in size from $0.2 \mathrm{~cm}$ to $2 \mathrm{~cm}$ are found especially on the trunk and limbs, the face and neck being seldom involved [23]. Although they may be asymptomatic, pain or paresthesias associated with these skin lesions are common complaints [7]. Exposure to cold, trauma, even touch, as well as emotional stress can induce local pain [24]. Nevertheless, the symptoms can be present independent of such precipitating factors. Moreover, cutaneous leiomyomas may exhibit a pseudoDarier sign [25]. The diagnosis should be confirmed by HP examination, that reveals a poorly circumscribed tumor located in the reticular dermis composed of bundles of smooth muscle fibers with eosinophilic cytoplasm and typical elongated nuclei with blunt ends, interlaced with collagen fibers [17, 24, 26, 27]. Immunohistochemistry studies show positivity for desmin and actin [28].

Malignant transformation into leiomyosarcomas has been described in HLRCC patients, but it is extremely uncommon [9, 29].

Another hallmark of the disease is uterine leiomyomatosis, which affects $70-90 \%$ of female family members $[9,26,30]$. In a study that included 108 patients diagnosed with HLRCC, $7 \%$ of women only presented uterine leiomyomas [30]. Similar to their cutaneous counterparts, uterine leiomyomas develop at young ages, the median age at diagnosis being 30 [26]. Compared to the general population, HLRCC patients develop multiple and larger uterine fibroids that cause pelvic pain, menstrual irregularities, menorrhagia, and fertility problems [31]. Due to rapid growth and severe associated symptoms, myomectomy or hysterectomy are frequently performed approximately 10 years earlier compared to the general population $[26$, 32-34]. Despite their benign nature, they tend to display increased cellularity, atypia, nuclear pleomorphism, and rare mitoses on HP examination [35]. Uterine leiomyosarcoma has been reported [29].

$10-30 \%$ of patients develop $\mathrm{RCC}[11,34,36]$, especially type 2 papillary RCC, and less frequently tubulopapillary, or collecting-duct RCC [37]. It usually occurs during the fourth or fifth decade of life $[34,38]$. As a rule, it is solitary and may be asymptomatic or manifest as hematuria and lower back pain [39]. Histopathologically, it is characterized by cells with large nuclei with eosinophilic inclusion-like nucleoli and a clear perinucleolar halo [40]. Tubulo-papillary, tubulo-solid, cystic, sarcomatoid patterns can be encountered and even a mixture of multiple patterns within the same tumor can be observed [40,
41]. Unfortunately, RCC is extremely aggressive in the majority of HLRCC patients, owing to its remarkable metastatic propensity. Metastazation to draining lymph nodes or distant sites is very frequent even with infracentimetric primary tumors. $82 \%$ of the 182 patients with HLRCC studied by Muller et al. already had metastatic disease at the time of diagnosis [42]. Systemic therapy has proven inefficient in this setting [43]. Therefore, it is crucial that patients diagnosed with HLRCC undergo regular and thorough renal imaging, as well as prompt surgical intervention in case renal tumors are detected. Screening for RCC should be performed by experienced physicians as benign renal cysts are also very common in patients with HLRCC (36\%) [44]. This is also the case in our patient, who has not developed RCC, but presents multiple renal cysts. The problem requires further investigation as association of HLRCC with renal cysts might not be purely coincidental and the later could also represent a predisposing factor for RCC [45].

Several case reports describe associations of HLRCC with adrenal cortical hyperplasia, pheochromocytoma, and adrenal cortical carcinoma [46]. In the study conducted by Shuch et al., 20 of 255 patients with HLRCC had micronodular and/or macronodular adrenal hyperplasia, justifying the assumption that these may represent additional elements of HLRCC [47]. Although initially suspected, the presence of a neuroendocrine tumor could not be demonstrated in our patient. Nevertheless, she was diagnosed with bilateral adrenal cortical hyperplasia.

Other solid tumors, such as breast cancer, bladder cancer, and testicular Leydig cell tumors have been described in association with HLRCC in isolated case reports [46].

The presence of multiple cutaneous leiomyomas confirmed by HP examination is considered a major criterion for the diagnosis of HLRCC. Minor criteria include surgery required for symptomatic uterine leiomyomata before 40 years of age, type 2 papillary RCC before 40 years of age, or a first-degree relative who meets one of the above criteria [48]. Either the major criterion or at least two minor criteria should be met in order to establish the diagnosis. Our patients met all criteria except the development of RCC. The definitive diagnosis is made once a germline $F H$ mutation or reduced enzyme activity is demonstrated [37]. Genetic counseling should be offered to both patients and their families and screening for RCC should be planned. There is no consensus regarding the age the surveillance should be initiated, but many authors recommend biannual renal US and annual abdominal and pelvic MRI, starting at the age of 10 [48, 49]. Adult female family members should also undergo annual gynecological examination, as well as periodic US and pelvic MRI.

Asymptomatic cutaneous leiomyomas do not require treatment. Surgical excision is the treatment of choice for single or few painful lesions, but recurrences are frequent. Cryotherapy, electrotherapy, or laser vaporization are also efficient for isolated tumors. Drugs that inhibit the contraction of smooth muscle fibers (calcium-channel blockers, $\alpha$-adrenergic receptor antagonists) and those that influence nerve activity (Gabapentin, topical analgesics) have been tried with little benefit in cases with numerous 
symptomatic cutaneous leiomyomas [2, 17, 24]. Botulinum toxin type A has recently been proposed as an alternative for pain control [50].

Uterine leiomyomas require myomectomy and in severe cases, hysterectomy. Gonadotropin-releasing hormone agonists and anti-hormonal treatment can be employed prior to surgery for tumor size reduction and temporary pain relief [34].

Considering the aggressive nature of $\mathrm{RCC}$ in these patients, no renal solid mass, even infracentimetric tumors should be monitored, but promptly excised with wide surgical margins. Radical nephrectomy and retroperitoneal lymph node dissection are often necessary [51].

Metastatic RCC in these patients portends a very poor prognosis, as no therapy has proven efficient in halting the progression of the disease so far. Multiple agents targeting vascular endothelial growth factor receptor (Bevacizumab), epidermal growth factor receptor (Erlotinib) or both (Vandetanib) are currently studied, either as monotherapy or in combination [52]. Metformin is also investigated for its synergistic effect with the previously mentioned treatments due to its antineoplastic properties. Antiprogrammed death ligand-1 (PDL-1) agents are only effective in the very rare tumors that are positive for PDL-1 [53]. Lactate dehydrogenase-A inhibitors and deoxyribonucleic acid (DNA) methyl transferase inhibitors (Guadecitabine) are also under evaluation [54].

\section{ㅁ Conclusions}

We wish to underscore the value of a thorough dermatological examination that can provide useful clues for the diagnosis of severe underlying systemic diseases. In our patient, an apparently unimportant cutaneous finding lead to the diagnosis of a serious genetic syndrome, with a high risk of aggressive RCC. Although the patient and her family members had presented skin and uterine tumors suggestive of HLRCC long before the admission to our Clinic, the diagnosis was missed owing to the rarity of the condition. HLRCC must be suspected in all individuals with multiple cutaneous leiomyomas. Referral to gynecology and nephrology specialists should not be delayed and a surveillance plan should be started as early detection of $\mathrm{RCC}$ is the only efficient strategy to reduce morbidity and mortality in HLRCC patients. A high index of suspicion and a low threshold for surgical intervention are essential when renal tumors are detected. Genetic counseling should also be offered to the patient and his family.

\section{Conflict of interests}

The authors declare that they have no conflict of interests.

\section{Compliance with ethical standards}

We obtained the approval of the Ethics Committee of Elias Emergency University Hospital, Bucharest for the publication of this manuscript (No. 4770/24.07.2020).

\section{Consent}

Written informed consent was obtained from the patient for publication of this case report and accompanying images.

\section{References}

[1] Kloepfer HW, Krafchuk J, Derbes V, Burks J. Hereditary multiple leiomyoma of the skin. Am J Hum Genet, 1958, 10(1):48-52. PMID: 13520698 PMCID: PMC1931875

[2] Reed WB, Walker R, Horowitz R. Cutaneous leiomyomata with uterine leiomyomata. Acta Derm Venereol, 1973, 53(5): 409-416. PMID: 4127477

[3] Arenas Valencia C, Rodríguez López ML, Cardona Barreto AY, Garavito Rodríguez E, Arteaga Díaz CE. Hereditary leiomyomatosis and renal cell cancer syndrome: identification and clinical characterization of a novel mutation in the $\mathrm{FH}$ gene in a Colombian family. Fam Cancer, 2017, 16(1):117-122. https://doi.org/10.1007/s10689-016-9922-4 PMID: 27566483

[4] Emer JJ, Solomon S, Mercer SE. Reed's syndrome: a case of multiple cutaneous and uterine leiomyomas. J Clin Aesthet Dermatol, 2011, 4(12):37-42. PMID: 22191007 PMCID: PMC3244358

[5] Alam NA, Rowan AJ, Wortham NC, Pollard PJ, Mitchell M, Tyrer JP, Barclay E, Calonje E, Manek S, Adams SJ, Bowers PW, Burrows NP, Charles-Holmes R, Cook LJ, Daly BM, Ford GP, Fuller LC, Hadfield-Jones SE, Hardwick N, Highet AS, Keefe M, MacDonald-Hull SP, Potts EDA, Crone M, Wilkinson S, Camacho-Martinez F, Jablonska S, Ratnavel R, MacDonald A, Mann RJ, Grice K, Guillet G, Lewis-Jones MS, McGrath H, Seukeran DC, Morrison PJ, Fleming S, Rahman S, Kelsell D, Leigh I, Olpin S, Tomlinson IPM. Genetic and functional analyses of $\mathrm{FH}$ mutations in multiple cutaneous and uterine leiomyomatosis, hereditary leiomyomatosis and renal cancer, and fumarate hydratase deficiency. Hum Mol Genet, 2003, 12(11):1241-1252. https://doi.org/10.1093/hmg/ddg148 PMID: 12761039

[6] Choudhary S, McLeod M, Torchia D, Romanelli P. Multiple cutaneous and uterine leiomyomatosis syndrome: a review. J Clin Aesthet Dermatol, 2013, 6(4):16-21. PMID: 23630637 PMCID: PMC3638850

[7] Schmidt LS, Linehan WM. Hereditary leiomyomatosis and renal cell carcinoma. Int J Nephrol Renovasc Dis, 2014, 7:253-260. https://doi.org/10.2147/IJNRD.S42097 PMID: 25018647 PMCID: PMC4074185

[8] Castro-Vega LJ, Buffet A, De Cubas AA, Cascón A, Menara M, Khalifa E, Amar L, Azriel S, Bourdeau I, Chabre O, CurrásFreixes M, Franco-Vidal V, Guillaud-Bataille M, Simian C, Morin A, Letón R, Gómez-Graña A, Pollard PJ, Rustin P, Robledo M, Favier J, Gimenez-Roqueplo AP. Germline mutations in $\mathrm{FH}$ confer predisposition to malignant pheochromocytomas and paragangliomas. Hum Mol Genet, 2014, 23(9):24402446. https://doi.org/10.1093/hmg/ddt639 PMID: 24334767

[9] Lehtonen HJ. Hereditary leiomyomatosis and renal cell cancer: update on clinical and molecular characteristics. Fam Cancer, 2011, 10(2):397-411. https://doi.org/10.1007/s10689-011-9428-z PMID: 21404119

[10] Badeloe S, Frank J. Clinical and molecular genetic aspects of hereditary multiple cutaneous leiomyomatosis. Eur J Dermatol, 2009, 19(6):545-551. https://doi.org/10.1684/ejd.2009.0749 PMID: 19939761

[11] Wei MH, Toure O, Glenn GM, Pithukpakorn M, Neckers L, Stolle C, Choyke P, Grubb R, Middelton L, Turner ML, Walther MM, Merino MJ, Zbar B, Linehan WM, Toro JR. Novel mutations in $\mathrm{FH}$ and expansion of the spectrum of phenotypes expressed in families with hereditary leiomyomatosis and renal cell cancer. J Med Genet, 2006, 43(1):1827. https://doi.org/10.1136/jmg.2005.033506 PMID: 15937070 PMCID: PMC2564499

[12] Vocke CD, Ricketts CJ, Merino MJ, Srinivasan R, Metwalli AR, Middelton LA, Peterson J, Yang Y, Linehan WM. Comprehensive genomic and phenotypic characterization of germline $\mathrm{FH}$ deletion in hereditary leiomyomatosis and renal cell carcinoma. Genes Chromosomes Cancer, 2017, 56(6):484-492. https://doi.org/10.1002/gcc.22452 PMID: 28196407 PMCID: PMC6637959

[13] Semenza GL. Oxygen homeostasis. Wiley Interdiscip Rev Syst Biol Med, 2010, 2(3):336-361. https://doi.org/10.1002/ wsbm.69 PMID: 20836033

[14] Dhani N, Fyles A, Hedley D, Milosevic M. The clinical significance of hypoxia in human cancers. Semin Nucl Med, 2015, 45(2):110-121. https://doi.org/10.1053/j.semnuclmed.2014.11. 002 PMID: 25704384 
[15] Isaacs JS, Jung YJ, Mole DR, Lee S, Torres-Cabala C, Chung YL, Merino M, Trepel J, Zbar B, Toro J, Ratcliffe PJ, Linehan WM, Neckers L. HIF overexpression correlates with biallelic loss of fumarate hydratase in renal cancer: novel role of fumarate in regulation of HIF stability. Cancer Cell, 2005, 8(2):143-153. https://doi.org/10.1016/j.ccr.2005.06.017 PMID: 16098467

[16] Sudarshan S, Sourbier C, Kong HS, Block K, Valera Romero VA, Yang Y, Galindo C, Mollapour M, Scroggins B, Goode N, Lee MJ, Gourlay CW, Trepel J, Linehan WM, Neckers L. Fumarate hydratase deficiency in renal cancer induces glycolytic addiction and hypoxia-inducible transcription factor 1 alpha stabilization by glucose-dependent generation of reactive oxygen species. Mol Cell Biol, 2009, 29(15): 4080-4090. https://doi.org/10.1128/MCB.00483-09 PMID: 19470762 PMCID: PMC2715796

[17] Kim G. Multiple cutaneous and uterine leiomyomatosis (Reed's syndrome). Dermatol Online J, 2005, 11(4):21. PMID: 16403393

[18] Barker KT, Bevan S, Wang R, Lu YJ, Flanagan AM, Bridge JA, Fisher C, Finlayson CJ, Shipley J, Houlston RS. Low frequency of somatic mutations in the $\mathrm{FH} /$ multiple cutaneous leiomyomatosis gene in sporadic leiomyosarcomas and uterine leiomyomas. Br J Cancer, 2002, 87(4):446-448. https://doi.org/ 10.1038/sj.bjc.660502 PMID: 12177782 PMCID: PMC2376129

[19] Kiuru M, Lehtonen R, Arola J, Salovaara R, Järvinen $H$, Aittomäki K, Sjöberg J, Visakorpi T, Knuutila S, Isola J, Delahunt B, Herva R, Launonen V, Karhu A, Aaltonen LA. Few $F H$ mutations in sporadic counterparts of tumor types observed in hereditary leiomyomatosis and renal cell cancer families. Cancer Res, 2002, 62(16):4554-4557. PMID: 12183404

[20] Launonen V, Vierimaa O, Kiuru M, Isola J, Roth S, Pukkala E, Sistonen P, Herva R, Aaltonen LA. Inherited susceptibility to uterine leiomyomas and renal cell cancer. Proc Natl Acad Sci U S A, 2001, 98(6):3387-3392. https://doi.org/10.1073/ pnas.051633798 PMID: 11248088 PMCID: PMC30663

[21] Fischer WC, Helwig EB. Leiomyomas of the skin. Arch Dermatol, 1963, 88(5):510-520. https://doi.org/10.1001/arch derm.1963.01590230018002 PMID: 14060062

[22] Adams A, Sharpe KK, Peters P, Freeman M. Hereditary leiomyomatosis and renal cell cancer (HLRCC): cutaneous and renal manifestations requiring a multidisciplinary team approach. BMJ Case Rep, 2017, 2017:bcr2016215115. https:// doi.org/10.1136/bcr-2016-21511 PMID: 28400389 PMCID: PMC5543308

[23] Garman ME, Blumberg MA, Ernst R, Raimer SS. Familial leiomyomatosis: a review and discussion of pathogenesis. Dermatology, 2003, 207(2):210-213. https://doi.org/10.1159/ 000071802 PMID: 12920381

[24] García Muret MP, Pujol RM, Alomar A, Calaf J, de Moragas JM. Familial leiomyomatosis cutis et uteri (Reed's syndrome). Arch Dermatol Res, 1988, 280(Suppl):S29-S32. PMID: 3408259

[25] Mandal RK, Koley S, Banerjee S, Kabiraj SP, Ghosh SK, Kumar P. Familial leiomyomatosis cutis affecting nine family members in two successive generations including four cases of Reed's syndrome. Indian J Dermatol Venereol Leprol, 2013, 79(1):83-87. https://doi.org/10.4103/0378-6323.104674 PMID: 23254734

[26] Alam NA, Barclay E, Rowan AJ, Tyrer JP, Calonje E, Manek S, Kelsell D, Leigh I, Olpin S, Tomlinson IP. Clinical features of multiple cutaneous and uterine leiomyomatosis: an underdiagnosed tumor syndrome. Arch Dermatol, 2005, 141(2):199-206. https://doi.org/10.1001/archderm.141.2.199 PMID: 15724016

[27] Kilpatrick SE, Mentzel T, Fletcher CD. Leiomyoma of deep soft tissue. Clinicopathologic analysis of a series. Am J Surg Pathol, 1994, 18(6):576-582. https://doi.org/10.1097/000004 78-199406000-00003 PMID: 8179073

[28] Miettinen M, Lehto VP, Virtanen I. Antibodies to intermediate filament proteins. The differential diagnosis of cutaneous tumors. Arch Dermatol, 1985, 121(6):736-741. PMID: 2408582

[29] Ylisaukko-oja SK, Kiuru M, Lehtonen HJ, Lehtonen R, Pukkala E, Arola J, Launonen V, Aaltonen LA. Analysis of fumarate hydratase mutations in a population-based series of early onset uterine leiomyosarcoma patients. Int J Cancer, 2006, 119(2):283-287. https://doi.org/10.1002/ijc.21798 PMID: 16477632
[30] Alam NA, Olpin S, Leigh IM. Fumarate hydratase mutations and predisposition to cutaneous leiomyomas, uterine leiomyomas and renal cancer. Br J Dermatol, 2005, 153(1):1117. https://doi.org/10.1111/j.1365-2133.2005.06678.x PMID: 16029320

[31] Tolvanen J, Uimari O, Ryynänen M, Aaltonen LA, Vahteristo P. Strong family history of uterine leiomyomatosis warrants fumarate hydratase mutation screening. Hum Reprod, 2012, 27(6):1865-1869. https://doi.org/10.1093/humrep/des105 PMID: 22473397

[32] Farquhar CM, Steiner CA. Hysterectomy rates in the United States 1990-1997. Obstet Gynecol, 2002, 99(2):229-234. https://doi.org/10.1016/s0029-7844(01)01723-9 PMID: 11814502

[33] Stewart L, Glenn GM, Stratton P, Goldstein AM, Merino MJ, Tucker MA, Linehan WM, Toro JR. Association of germline mutations in the fumarate hydratase gene and uterine fibroids in women with hereditary leiomyomatosis and renal cell cancer. Arch Dermatol, 2008, 144(12):1584-1592. https://doi.org/ 10.1001/archdermatol.2008.517 PMID: 19075141 PMCID: PMC2937541

[34] Toro JR, Nickerson ML, Wei MH, Warren MB, Glenn GM, Turner ML, Stewart L, Duray P, Tourre O, Sharma N, Choyke P, Stratton P, Merino M, Walther MM, Linehan WM, Schmidt LS, Zbar B. Mutations in the fumarate hydratase gene cause hereditary leiomyomatosis and renal cell cancer in families in North America. Am J Hum Genet, 2003, 73(1):95-106. https://doi.org/10.1086/376435 PMID: 12772087 PMCID: PMC1180594

[35] Sanz-Ortega J, Vocke C, Stratton P, Linehan WM, Merino MJ. Morphologic and molecular characteristics of uterine leiomyomas in hereditary leiomyomatosis and renal cancer (HLRCC) syndrome. Am J Surg Pathol, 2013, 37(1):74-80. https://doi.org/ 10.1097/PAS.0b013e31825ec16f PMID: 23211287 PMCID: PMC3524342

[36] Alam NA, Bevan S, Churchman M, Barclay E, Barker K, Jaeger EE, Nelson HM, Healy E, Pembroke AC, Friedmann PS, Dalziel K, Calonje E, Anderson J, August PJ, Davies MG, Felix R, Munro CS, Murdoch M, Rendall J, Kennedy S, Leigh IM, Kelsell DP, Tomlinson IP, Houlston RS. Localization of a gene (MCUL1) for multiple cutaneous leiomyomata and uterine fibroids to chromosome 1q42.3-q43. Am J Hum Genet, 2001, 68(5):1264-1269. https://doi.org/10.1086/320124 PMID: 11283798 PMCID: PMC1226106

[37] Kamihara J, Schultz KA, Rana HQ. FH tumor predisposition syndrome. In: Adam MP, Ardinger HH, Pagon RA, Wallace SE, Bean LJH, Stephens K, Amemiya A (eds). GeneReviews ${ }^{\circledR}$ [Internet]. University of Washington, Seattle, WA, 1993-2020 [Initial posting: July 31, 2006; Last revision: August 13, 2020]. http://www.ncbi.nlm.nih.gov/books/NBK1252/ PMID: 20301430

[38] Linehan WM, Walther MM, Zbar B. The genetic basis of cancer of the kidney. J Urol, 2003, 170(6 Pt 1):2163-2172. https://doi.org/10.1097/01.ju.0000096060.92397.ed PMID: 14634372

[39] Fleming S, Amin MB, Storkel S. Collecting duct carcinoma. In: Moch $\mathrm{H}$, Humphrey PA, Ulbright TM, Reuter VE (ed). World Health Organization (WHO) Classification of tumours of the urinary system and male genital organs. $4^{\text {th }}$ edition, vol. 8, WHO Classification of Tumours, International Agency for Research on Cancer (IARC) Press, Lyon, France, 2016, 29-30.

[40] Merino MJ, Torres-Cabala C, Pinto P, Linehan WM. The morphologic spectrum of kidney tumors in hereditary leiomyomatosis and renal cell carcinoma (HLRCC) syndrome. Am J Surg Pathol, 2007, 31(10):1578-1585. https://doi.org/ 10.1097/PAS.0b013e31804375b8 PMID: 17895761

[41] Merino MJ, Torres-Cabala CA, Zbar B, Chian Garcia CA, Linehan WM. Hereditary leiomyomatosis and renal cell carcinoma syndrome (HLRCC): clinical, histopathological and molecular features of the first American families described [Abstract]. Mod Pathol, 2003, 16(Suppl):739.

[42] Muller M, Ferlicot S, Guillaud-Bataille M, Le Teuff G, Genestie C, Deveaux S, Slama A, Poulalhon N, Escudier B, Albiges L, Soufir N, Avril MF, Gardie B, Saldana C, Allory Y, GimenezRoqueplo AP, Bressac-de Paillerets B, Richard S, Benusiglio PR. Reassessing the clinical spectrum associated with hereditary leiomyomatosis and renal cell carcinoma syndrome in French 
FH mutation carriers. Clin Genet, 2017, 92(6):606-615. https:// doi.org/10.1111/cge.13014 PMID: 28300276

[43] Sudarshan S, Pinto PA, Neckers L, Linehan WM. Mechanisms of disease: hereditary leiomyomatosis and renal cell cancer - a distinct form of hereditary kidney cancer. Nat Clin Pract Urol, 2007, 4(2):104-110. https://doi.org/10.1038/ncpuro0711 PMID: 17287871

[44] Gupta G, Sudan R, Mushtaq S. Multiple cutaneous and uterine leiomyomatosis with renal involvement: report of a rare association. Indian J Dermatol, 2018, 63(1):73-75. https:// doi.org/10.4103/ijd.IJD_355_17 PMID: 29527031 PMCID: PMC5838760

[45] Almeida FT, Santos RP, Carvalho SD, Brito MC. Reed's syndrome. Indian J Dermatol, 2018, 63(3):261-263. https:// doi.org/10.4103/ijd.IJD_69_18 PMID: 29937565 PMCID: PMC5996637

[46] Skala SL, Dhanasekaran SM, Mehra R. Hereditary leiomyomatosis and renal cell carcinoma syndrome (HLRCC): a contemporary review and practical discussion of the differential diagnosis for HLRCC-associated renal cell carcinoma. Arch Pathol Lab Med, 2018, 142(10):1202-1215. https://doi.org/ 10.5858/arpa.2018-0216-RA PMID: 30281371

[47] Shuch B, Ricketts CJ, Vocke CD, Valera VA, Chen CC, Gautam R, Gupta GN, Gomez Macias GS, Merino MJ, Bratslavsky G, Linehan WM. Adrenal nodular hyperplasia in hereditary leiomyomatosis and renal cell cancer. J Urol, 2013, 189(2):430-435. https://doi.org/10.1016/j.juro.2012.07.139 PMID: 22982371 PMCID: PMC4435969

[48] Smit DL, Mensenkamp AR, Badeloe S, Breuning MH, Simon MEH van Spaendonck KY, Aalfs CM, Post JG, Shanley S, Krapels IPC, Hoefsloot LH, van Moorselaar RJA, Starink TM, Bayley JP, Frank J, van Steensel MAM, Menko FH. Hereditary leiomyomatosis and renal cell cancer in families referred for fumarate hydratase germline mutation analysis. Clin Genet, 2011, 79(1): 49-59. https://doi.org/10.1111/j.1399-0004.2010.01486.x PMID: 20618355
[49] Lehtonen HJ, Kiuru M, Ylisaukko-Oja SK, Salovaara R, Herva R, Koivisto PA, Vierimaa O, Aittomäki K, Pukkala E, Launonen V, Aaltonen LA. Increased risk of cancer in patients with fumarate hydratase germline mutation. J Med Genet, 2006, 43(6):523526. https://doi.org/10.1136/jmg.2005.036400 PMID: 16155190 PMCID: PMC2564537

[50] Naik HB, Steinberg SM, Kong HH, Cowen EW. Human Clinical Research and Therapeutics - Abstract 533: Botulinum toxin improves quality of life and may ameliorate pain associated with cutaneous leiomyomas. J Invest Dermatol, 2014, 134(Suppl 1): S93. https://doi.org/10.1038/jid.2014.109

[51] Menko FH, Maher ER, Schmidt LS, Middelton LA, Aittomäki K, Tomlinson I, Richard S, Linehan WM. Hereditary leiomyomatosis and renal cell cancer (HLRCC): renal cancer risk, surveillance and treatment. Fam Cancer, 2014, 13(4):637-644. https://doi.org/10.1007/s10689-014-9735-2 PMID: 25012257 PMCID: PMC4574691

[52] Linehan WM, Srinivasan R, Garcia JA. Non-clear cell renal cancer: disease-based management and opportunities for targeted therapeutic approaches. Semin Oncol, 2013, 40(4): 511-520. https://doi.org/10.1053/j.seminoncol.2013.05.009 PMID: 23972715 PMCID: PMC4165483

[53] Alaghehbandan R, Stehlik J, Trpkov K, Magi-Galluzzi C, Condom Mundo E, Pane Foix M, Berney D, Sibony M, Suster S, Agaimy A, Montiel DP, Pivovarcikova K, Michalova K, Daum O, Ondic O, Rotterova P, Dusek M, Hora M, Michal M, Hes O. Programmed death-1 (PD-1) receptor/PD-1 ligand (PD-L1) expression in fumarate hydratase-deficient renal cell carcinoma. Ann Diagn Pathol, 2017, 29:17-22. https://doi.org/ 10.1016/j.anndiagpath.2017.04.007 PMID: 28807336

[54] Xie H, Valera VA, Merino MJ, Amato AM, Signoretti S, Linehan WM, Sukhatme VP, Seth P. LDH-A inhibition, a therapeutic strategy for treatment of hereditary leiomyomatosis and renal cell cancer. Mol Cancer Ther, 2009, 8(3):626-635. https://doi.org/10.1158/1535-7163.MCT-08-1049 PMID: 19276158 PMCID: PMC2671637

\section{Corresponding author}

Mara Mădălina Mihai, Assistant Professor, MD, PhD, Department of Dermatology, Elias Emergency University Hospital, Carol Davila University of Medicine and Pharmacy, 17 Mărăşti Avenue, Sector 1, 011461 Bucharest, Romania; Phone +4021-316 16 00, e-mail: mara.mihai@umfcd.ro 